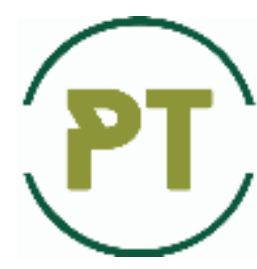

\title{
Evaluation of tribological characteristics of liquid lubricants with fullerene additives
}

\author{
A.G. Kravcov \\ Kharkov National Technical University of Agriculture named after Petro Vasylenko, Kharkiv, Ukraine \\ E-mail: kravcov@gmail.com
}

\begin{abstract}
The paper presents experimental studies of the tribological characteristics of liquid lubricants of various viscosity classes and various groups of operation when using fullerene additives. Tribological characteristics were evaluated on a four-ball friction machine according to GOST 9490. Assessment was subject to: wear rate and critical load, which characterize the anti-wear properties of the lubricant, as well as welding load and bully index, which characterize an anti-bully properties of the material.

It is shown that the improvement of the wear index for all oils begins with the concentration 0,2\% masses, fullerenes in the lubricant and does not exceed the values $11,1 \ldots 15 \%$. At a fullerene concentration less than $0,2 \%$ masses, no positive effect is observed. Positive effect $11,8 \ldots 17,4 \%$ characteristic of the indicator critical load that characterizes the range of performance of anti-wear additives. At the same time, an increase in the critical load begins with concentration 0,1\% masses, fullerenes in a lubricant and manifests itself most effectively at a concentration $0,2 \%$ masses. Changes in the magnitude of the welding load during the experiments were not recorded, this allows us to conclude, that the addition of a finely dispersed fullerene powder in a liquid lubricant does not improve anti-bully properties, but is only an anti-wear additive.

It is shown that the way to improve the tribological properties of lubricants by introducing a finely dispersed powder of fullerenes in base technical oils is ineffective. It is necessary to develop other, more technological methods and methods for introducing fullerene additives into technical lubricants.
\end{abstract}

Key words: four-ball friction machine; tribological characteristics; wear rate; critical load; welding load; bully index; fullerenes; technical oils.

\section{Introduction}

In modern condensed matter physics, great interest is shown in the study of nanostructures - systems with characteristic dimensions in the range 1-100 nm. In particular, such systems include fullerene clusters. The fullerene molecules themselves are a new allotropic form of carbon, discovered in 1985 year. The most stable of these is fullerene $\mathrm{C}_{60}$. Today, the use of fullerenes is of great interest $\mathrm{C}_{60}$, as additives to liquid lubricants. $\mathrm{A}$ number of scientific articles have appeared in recent years, where the results of studies of the effect of fullerene additives to lubricants on the processes of friction and wear of metals are presented and a conclusion is made about the prospects of using such additives.

An interesting and important feature of fullerene additives is that fullerenes are readily soluble in a wide class of organic and inorganic solvents. At the same time, poor solubility of fullerenes in industrial oils was noted (mineral, semi-synthetic and synthetic). To date, the solubility has been determined and analyzed $\mathrm{C}_{60}$ in a lot of liquids. It is shown that the solubility of fullerenes decreases with increasing polarity of the solvent. A number of unusual properties of fullerene solutions have been revealed, so for some solvents the effect of an anomalous dependence of the solubility of fullerene on temperature was found. At a temperature of about $280{ }^{\circ} \mathrm{K}$ the maximum solubility is observed in these systems $\mathrm{C}_{60}$, after which it starts to decrease.

Another interesting phenomenon observed in fullerene solutions $\mathrm{C}_{60}$, are the processes of formation and growth of clusters, which indicate the proximity of many solutions $\mathrm{C}_{60}$ to the class of colloidal systems. The defining moment of this phenomenon is the fact that the size of the fullerene lies on the border of the definition of the concept of a colloidal particle (according to colloidal chemistry, colloidal particles range in size from one nanometer to several micrometers). The polarity of the solvent also has a great influence on this process. 
The use of fullerene additives for technical liquid lubricants raises a number of questions about their effectiveness, i.e. influence on anti-wear and anti-bully properties. Interest in this phenomenon is of both fundamental and applied nature, which will allow the development of concepts for their application.

\section{Literature review}

The authors of the work [1] provides an overview of the literature on lubricants with added nanoparticles. The effect of nanoparticles on the tribotechnical characteristics of oils is analyzed. The work noted that the use of nano-additives to lubricants leads to an increase in the viscosity of the base environment, high bearing capacity of the interface, reducing the coefficient of friction, increasing wear resistance. Work [2] contains the conclusions that the characteristics of the lubricant can be improved by using nano-additives. Adding nanoparticles to conventional base oils is a promising avenue. The work is devoted to an informative review of the application of nano-additives to liquid lubricants and the prospects for its use in the production of oils. Similar conclusions about the prospects of using nanomaterials in liquid lubricants are made by the authors of the work [3].

The works [4 - 6] devoted to fullerenes as additives to lubricants. The authors note that the use of fullerenes reduces the coefficient of friction and increases the wear resistance of mates. In work [6] it is noted that the concentration of the fullerene additive should be within $0,5 \ldots 2,0 \%$ masses. In work [7] the result of using fullerene is given $\mathrm{C}_{60}$. The authors note a positive effect, however, they conclude that the mechanism of the senergism of fullerenes with base oil is unclear and requires further research. At the same time, it was noted in the work that a decrease in the friction coefficient with the addition of fullerenes to oils can reach $90 \%$ compared to base oil.

Analysis of works devoted to the use of fullerenes as additives to lubricants, allows us to conclude that fullerenes are not dispersed (dissolved) in all industrial oils [8 - 10].

\section{Purpose}

The purpose of this work is to carry out experimental studies of the tribological characteristics of liquid lubricants in the presence of fullerene additives in their composition.

\section{Methods}

The evaluation of tribological characteristics was carried out on a four-ball friction machine according to the method, set out in GOST 9490. The use of a four-ball friction machine is regulated by GOST 9490-75, in Germany DIN 51350, in USA ASTM D2783.

According to GOST 9490-75 the following indicators are determined.

1. Wear rate, $D_{w}$, dimension $\mathrm{mm}$, which is the arithmetic mean of the diameter of the wear spots of three fixed balls. Tests are performed under load $196 \mathrm{~N}$, test time 60 minutes.

Wear rate, $D_{w}, \mathrm{~mm}$, characterizes the presence in the lubricant of anti-wear additives. When less the value of wear, then more effective additives in the lubricant.

2. Critical load, $P_{c r}$, dimension N. Sets the limit when anti-wear additives lose their effectiveness. This is due to the heat generated in the contact zone of the balls with increasing load. Test time $-10 \mathrm{~s}$. The limit of loss of effectiveness of anti-wear additives is determined by the jump of wear spots of the lower balls more than 0,1 $\mathrm{mm}$ from the previous value. Critical load, $P_{c r}$ characterizes the range of anti-wear additives. When greater the critical load, then more effective the additives in the lubricant.

3. Welding load, $P_{\text {weld }}$, dimension N. Test time $-10 \mathrm{~s}$. Sets the limit when four balls are welded under load in lubricant during operation. GOST 9490-75 sets the limit on the diameter of the wear spots of the fixed lower balls. If the diameter is more than $3 \mathrm{~mm}$, the load is considered to be the welding load and further tests are stopped. Welding load, $P_{\text {weld }}$, characterizes the presence of anti-bully additives in the lubricant. As the load increases, due to the heat generated on the contact spots, the anti-bully additives lose their effectiveness. There is welding of balls in a pyramid, or fast wear of balls with transfer and spreading of material from a ball on a ball. When greater the welding load, then more effective the anti-bully additives in the lubricant.

4. Bully index $I_{b}$, dimension N. This is an integral characteristic of the lubricant, which combines antiwear and anti-bully properties of the lubricant. The greater the value of the bully index, the more effective antiwear and anti-bully additives in the lubricant.

GOST 9490-75 was used to test liquid lubricants for various purposes with fullerene additives and determine their effectiveness.

Experimental studies included the determination of tribological characteristics on a four-ball machine of liquid lubricants of the following operation groups:

- hydraulic mineral oil, by classification ISO corresponds to NM, viscosity class 10, trade mark MGP-10;

- engine oil, according to SAE 30 classification, API CC operation group, trade mark M-10G $2 \mathrm{k}$;

- gear oil, SAE 75W90 classification, API GL-5 service group, trade mark VALVOLINE. 
Fullerenes in the form of fine powder of various concentrations $F=0,05 \ldots 0,30 \%$, masses introduced into the above-listed technical base oils.

\section{Results}

The results of experimental studies for hydraulic oil MGP-10 are presented in the table 1, for engine oil $\mathrm{M}-10 \mathrm{G}_{2 \mathrm{k}}$ are presented in the table 2, for transmission oil VALVOLINE GL-5 are presented in the table 3 .

The experimental results were checked for reproducibility by Cochran's criterion according to the formulas (1), (2):

$$
G_{p}=\frac{S^{2}{ }_{\max }}{\sum_{i=1}^{N} S^{2}{ }_{i}}
$$

where $S_{\text {max }}^{2}$ - the maximum value of the variance for $D_{w}, P_{c r}, P_{\text {weld }}, I_{b}$ in accordance;

$S_{i}^{2}$ - the value of the variance $i$ - th experiment for $D_{w}, P_{c r}, P_{\text {weld }}, I_{b}$ in accordance.

The hypothesis was tested:

$$
G_{p}<G_{t a b}
$$

where $G_{t a b}$ - tabular value of the Cochren's criterion, with a given confidence level $q=0,90$.

In the process of experimental studies, the number of repeats of the same type was determined during the experiment, which make it possible to ensure the experimental error at the level of confidence equal to $q=0,90$. Calculation of the above indicators $D_{w}, P_{c r}, P_{\text {weld }}, I_{b}$ allows us to conclude that tests on a four-ball machine of liquid lubricants for various purposes with different concentrations of fullerenes are reproducible and reliable under the condition of three repeats of the same type. In tables $1-3$ the arithmetic mean values of three repeats of tribological characteristics are given.

Analysis of the data given in the tables 1 - 3 allows us to draw the following conclusions.

Wear indicator $D_{w}$ increases by $11,1 \ldots 15 \%$, at the same time, the larger value refers to the MGP-10 hydraulic oil, and the lower value refers to the transmission oil VALVOLINE GL-5. It follows from the tables that the improvement of the wear index, which characterizes antiwear properties, for all oils begins with the concentration 0,2 \% masses, fullerenes in lubricant. At a fullerene concentration less than 0,2 \% masses, no positive effect is observed. This allows us to conclude that there is a boundary in the concentration of fullerene additives in technical oils.

Table 1

Tribological characteristics of hydraulic oil MGP-10 with the addition of fullerenes $(F)$

\begin{tabular}{|c|c|c|c|c|}
\hline Lubricant & $D_{w}, \mathrm{~mm}$ & $P_{c r}, \mathrm{~N}$ & $P_{\text {weld }}, \mathrm{N}$ & $I_{b}, \mathrm{~N}$ \\
\hline MGP-10 & 0,65 & 784 & 1568 & 24 \\
\hline MGP-10+0,05 \% F & 0,6 & 784 & 1568 & 24 \\
\hline MGP-10+0,10 \% F & 0,6 & 823 & 1568 & 24 \\
\hline MGP-10+0,15\% F & 0,6 & 872 & 1568 & 26 \\
\hline MGP-10+0,20 \% F & 0,55 & 921 & 1568 & 27 \\
\hline MGP-10+0,30 \% F & 0,55 & 921 & 1568 & 27 \\
\hline
\end{tabular}

Table 2

Tribological characteristics of $\mathbf{M - 1 0 G} \mathrm{G}_{2 \mathrm{k}}$ engine oil with the addition of fullerenes $(F)$

\begin{tabular}{|c|c|c|c|c|}
\hline Lubricant & $D_{w}, \mathrm{~mm}$ & $P_{c r}, \mathrm{~N}$ & $P_{\text {weld }}, \mathrm{N}$ & $I_{b}, \mathrm{~N}$ \\
\hline${\mathrm{M}-10 \mathrm{G}_{2 \mathrm{k}}}$ & 0,45 & 1235 & 2450 & 28 \\
\hline $\mathrm{M}-10 \mathrm{G}_{2 \mathrm{k}}+0,05 \% \mathrm{~F}$ & 0,45 & 1235 & 2450 & 28 \\
\hline $\mathrm{M}-10 \mathrm{G}_{2 \mathrm{k}}+0,10 \% \mathrm{~F}$ & 0,45 & 1235 & 2450 & 29 \\
\hline $\mathrm{M}-10 \mathrm{G}_{2 \mathrm{k}}+0,15 \% \mathrm{~F}$ & 0,45 & 1235 & 2450 & 30 \\
\hline $\mathrm{M}-10 \mathrm{G}_{2 \mathrm{k}}+0,20 \% \mathrm{~F}$ & 0,4 & 1303 & 2450 & 31 \\
\hline $\mathrm{M}-10 \mathrm{G}_{2 \mathrm{k}}+0,30 \% \mathrm{~F}$ & 0,4 & 1381 & 2450 & 31 \\
\hline
\end{tabular}


Tribological characteristics of VALVOLINE GL-5 gear oil with the addition of fullerenes $(F)$

\begin{tabular}{|c|c|c|c|c|}
\hline Lubricant & $D_{w}, \mathrm{~mm}$ & $P_{c r}, \mathrm{~N}$ & $P_{\text {weld }}, \mathrm{N}$ & $I_{b}, \mathrm{~N}$ \\
\hline GL-5 & 0,45 & 1960 & 4900 & 76 \\
\hline GL-5 + 0,05 \% F & 0,45 & 1960 & 4900 & 76 \\
\hline GL-5 + 0,10 \% F & 0,45 & 1960 & 4900 & 78 \\
\hline GL-5 + 0,15 \% F & 0,45 & 2067 & 4900 & 80 \\
\hline GL-5 + 0,20 \% F & 0,4 & 2195 & 4900 & 82 \\
\hline GL-5 + 0,30 \% F & 0,4 & 2195 & 4900 & 82 \\
\hline
\end{tabular}

The positive effect is also typical for the index - critical load $P_{c r}$, which characterizes the range of performance of anti-wear additives, i.e. determines the anti-wear properties of the lubricant. The critical load is increased by $11,8 \ldots 17,4 \%$, the larger value refers to hydraulic oil, table 1 , and the smaller value - to the transmission oil, table 3. At the same time, an increase in the critical load for hydraulic oil begins with a concentration $0,1 \%$ masses, fullerenes in the lubricant and manifests itself most effectively in all oils at a concentration $0,2 \%$ masses. This experimental fact makes it possible to confirm the boundary for the concentration of fullerene additives in technical oils.

Changes in the value of the welding load $P_{\text {weld }}$ during the experiments, it was not recorded, this allows us to conclude that the addition of finely dispersed fullerene powder in a liquid lubricant does not improve the anti-bully properties, but is only an anti-wear additive.

Bully index $I_{b}$, which characterizes the integral tribological characteristic of the lubricant increases by $7,8 \ldots 12,5 \%$, the larger value refers to the hydraulic oil and the lower value refers to the transmission oil.

The obtained values of the improvement of anti-wear properties coincide with the values obtained by other researchers, a review of whose work is given above.

Tests of lubricants on a four-ball friction machine are referred to as "hard" tests. For example, when determining the magnitude of the critical load and the welding load, the test time is 10 seconds. This requires the lubricant to quickly respond to changing external conditions and the formation of wear-resistant structures on the friction surface in a short time.

\section{Conclusions}

The introduction of fullerene additives in the form of a finely dispersed powder into technical oils of various viscosity classes and various groups of operation improves the anti-wear properties of oils, which are estimated by the wear index (increase by $11,1 \ldots 15 \%$ ) and critical load (increase by $11,8 \ldots 17,4 \%$ ). Fullerene additives have no effect on the anti-bully properties of base oils, which are assessed by the bully load. This result makes it possible to state that the way to improve the tribological properties of lubricants by introducing a finely dispersed powder of fullerenes into base technical oils is ineffective. As follows from the above analysis of scientific works, such an insignificant effect is typical due to the intense clustering of fullerene molecules in the environment of industrial oils containing surfactants. Technical oils act as a highly polar solvent.

The experimental results presented allow us to conclude that it is necessary to develop other, more technological techniques and methods for introducing fullerene additives into technical lubricants, the theoretical justification of which was developed in the works $[11,12]$.

\section{References}

1. Singh Anurag, Chauhan Prashant, Mamatha T. G. A review on tribological performance of lubricants with nanoparticles additives // Materials today: proceedings Volume 25, Part 4, 2020, Pages 586-591 https://doi.org/10.1016/j.matpr.2019.07.245 [English]

2. Shahnazar Sheida, Bagheri Samira, Sharifah Bee Abd Hamid Enhancing lubricant properties by nanoparticle additives // International Journal of Hydrogen Energy Volume 41, Issue 4, 2015, Pages 3153-3170 https://doi.org/10.1016/j.ijhydene.2015.12.040 [English]

3. Ali Imran, Basheer Al Arsh, Kucherova Anastasia, Memetov Nariman, Pasko Tatiana, Ovchinnikov Kirill, Pershin Vladimir, Kuznetsov Denis, Galunin Evgeny, Grachev Vladimir, Tkachev Alexey Advances in carbon nanomaterials as lubricants modifiers // Journal of Molecular Liquids Volume 279, 2019, Pages 251-266 https://doi.org/10.1016/j.molliq.2019.01.113 [English]

4. Yao Yanli, Wang Xiaomin, Guo Junjie, Yang Xiaowei, Xu Bingshe Tribological property of onion-like fullerenes as lubricant additive // Materials Letters Volume 62, Issue 16, 2007, Pages 2524-2527 https://doi.org/10.1016/j.matlet.2007.12.056 [English]

5. Rapoport L., Feldman Y., Homyonfer M., Cohen H., Sloan J., Hutchison J. L., Tenne R. Inorganic fullerene-like material as additives to lubricants: structure-function relationship // Wear Volumes 225-229, Part 2, 1999, Pages 975-982 https://doi.org/10.1016/S0043-1648(99)00040-X [English] 
6. Yunusov F. A., Breki A. D., Vasilyeva E. S., Tolochko O. V. The influence of nano additives on tribological properties of lubricant oil // Materials today: proceedings Available online 14 February 2020 https://doi.org/10.1016/j.matpr.2020.01.447 [English]

7. Xiaowei Li, Xiaowei $\mathrm{Xu}$, Yong Zhou, Kwang-Ryeol Lee, Aiying Wang Insights into friction dependence of carbon nanoparticles as oil-based lubricant additive at amorphous carbon interface // Carbon Volume 150, 2019, Pages 465-474 https://doi.org/10.1016/j.carbon.2019.05.050 [English]

8. Bezmel'nitsyn V. N., Yeletskiy A. V., Okun' M. V. Fullereny v rastvorakh // Uspekhi fizicheskikh nauk. — 1998, № 11, 1195-1220 [Russian]

9. Gindzburg B. M., Baydakova M. V., Kireyenko O. F. [i dr.]. Vliyaniye fullerenov C60, fullerenovykh sazh i drugikh uglerodnykh materialov na granichnoye treniye skol'zheniye metallov // Zhurnal tekhnicheskoy fiziki. — 2000, № 12, 87—97 [Russian]

10. Yakh'yayev N. YA., Begov ZH. B., Batyrmurzayev SH. D. Novaya smazochnaya kompozitsiya dlya modifikatsii poverkhnostey tribosopryazheniy sudovogo malorazmernogo dizelya // Vestnik AGTU. Ser.: Morskaya tekhnika i tekhnologiya. — 2009, № 1, 47-52 [Russian]

11. Kravcov A. G. Razrabotka matematicheskoy modeli vzaimodeystviya elektricheski aktivnykh geterogennykh melkodispersnykh sistem na granitse razdela poverkhnost' treniya - smazochnaya sreda // Problemi tribologíi. — 2017, № 1, 89-99 [Russian]

12. Kravcov A. G. Modelirovaniye formirovaniya maslyanoy plenki na poverkhnosti treniya pri nalichii fullerenovykh dobavok $\mathrm{v}$ smazochnom materiale i yeye vliyaniye na skorost' iznashivaniya tribosistem // Problemi tribologií. — 2018, № 1, 69-77 [Russian]

Кравцов А.Г. Оцінка трибологічних характеристик рідких мастильних матеріалів з фулереновими добавками.

В роботі представлені експериментальні дослідження трибологічних характеристик рідких мастильних матеріалів різного класу в'язкості і різних груп експлуатації при використанні фулеренових добавок. Трибологічні характеристики оцінювалися на четирьохкульковій машині тертя згідно ГОСТ 9490. Оцінки підлягали: показник зносу і критичне навантаження, які характеризують протизносні властивості мастильного матеріалу, а також навантаження зварювання i iндекс задира, які характеризують протизадирні властивості матеріалу.

Показано, що поліпшення показника зносу для всіх олив починається з концентрації 0,2 \% мас., фулеренів в змащувальному матеріалі і не перевищує значень 11,1 ... 15 \%. При концентрації фулеренів менше 0,2 \% мас., позитивного ефекту не спостерігається. Позитивний ефект 11,8 ... 17,4 \% характерний i для показника - критичне навантаження, яке характеризує діапазон роботи протизносних присадок. При цьому, збільшення критичного навантаження починається 3 концентрації 0,1 \% мас., фулеренів в змащувальному матеріалі і найбільш ефективно проявляється при концентрації 0,2 \% мас. Зміни величини навантаження зварювання в процесі проведення експерименту не зафіксовано, це дозволяє зробити висновок, що добавка дрібнодисперсного фулеренового порошку в рідкому змащувальному матеріалі не покращує протизадирних властивостей, а є тільки протизносною добавкою.

Показано, що шлях поліпшення трибологічних властивостей мастильних матеріалів шляхом введення дрібнодисперсного порошку фулеренів в базові технічні оливи є малоефективним. Необхідно розробляти інші, більш технологічні прийоми і методи введення фулеренових добавок в технічні мастильні оливи.

Ключові слова: чотирьохкулькова машина тертя; трибологічні характеристики; показник зноса; критичне навантаження; навантаження зварювання; індекс задира; фулерени; технічні оливи. 